\title{
Evaluation of plasma Creatine Kinase activity and Inorganic phosphate among Sudanese patients with sickle cell disease in Khartoum and White Nile state
}

\author{
Elgaili A.K. Khowgali ${ }^{1}$, Husham O. Elzein ${ }^{2}$, NassrEldin M.A.Shrif ${ }^{3}$, \\ Amna O.M.Elzein ${ }^{3 *}$

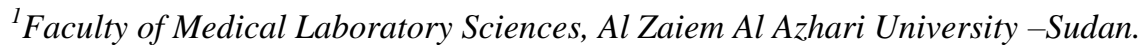 \\ ${ }^{2}$ Faculty of medical laboratory science, University of science and technology, Omdurman, Sudan \\ ${ }^{3}$ Department of clinical chemistry, faculty of Medical laboratory Sciences, Al zaiem Al Azhari University-Sudan.
}

\begin{abstract}
Background: $C K$ and phosphorus are helpful biomarker for detection of early renalabnormality particularlyCK which has been shown to be abetter predicator of acute renal failure.

Objectives: This is a descriptive cross-sectional study. Conducted in Khartoum and White Nile state from March to June 2016.The aim of this study to assess serum creatine kinase (CK) activity and inorganic phosphate concentrations in Sudanese patients with sickle cell anemia. 80 subjects were enrolled in this study they were classified into 40 with sickle cell disease (SCD) as casegroup and 40 healthy apparently as control group. CK activity and phosphorus level was measured by using Spectrophotometry method.

Results: The results showed significantly higher Ck activity in patients with SCD when compared with control group with $(P=0.021)$, and not significant differences in mean of serum phosphorus concentration in case when compared with control with $(P=0.547)$. Also show serum $C K$ activity in patients used hydroxyurea when compare with the mean of patients not used hydroxyurea it is significantly decrease with $(P=0.006)$.

Conclusion: The studies conclude that Sickle cell disease is a predictor for high serum CK activity and low serum concentration of inorganic phosphate.
\end{abstract}

\section{Introduction}

Sickle cell disease (SCD) is an inherited form of hemolytic anemia [1].About (5-7\%)of the global population carries an abnormal haemoglobin gene[2.3] .Highestprevalence of (SCD)occursinMiddle East, Mediterranean regions, Southeast Asia, and subSaharanAfrica [4,5,6,7].In Sudan the first case was reported in 1950 [8],andconsidered as the major haemoglobinopathy seen Khartoum, the capital of Sudan. This may be due to the migration of tribes from western Sudan as a result of drought and desertification in the 1970s and 1980s, and the conflicts in Darfur in 2005. These tribes are with thehighest rate of (SCD)in Western Sudan particularly Messeryia tribes in Darfur and Kordofan regions [9].(SCD) has so, various complications, including Vasoocclusive crisis (VOC), the hallmark of which is vascular occlusion and tissue ischemia which lead to organ damage $[10,11]$.Patients with sickle cell disease (SCD) may suffer from renaldysfunction from early childhood [12], usually; the renal medulla is not able to concentrate the urine due to episodesof ischemia affecting the area [13].Creatine kinase (CK) is an enzyme with a molecular weight of approximately 82,000 [14], it has a various isoforms. Serum levels of the muscle (MM) isoform have been found to be increased in conditions associated with tissue hypoxia and muscle necrosis and considered as a better predictor of acute renal failure due to rhabdomyolysis than creatinine and Urinary myoglobin[15,16].Inorganic phosphate is the measured fraction in serum orplasma by clinical laboratories [17].It is found free in plasma, and actively re-absorbed by the renal tubules so that serum concentrations are dependent on renal function, as a result high level of phosphate in the blood is usually caused by a kidney problem $[14,18]$. Hydroxyurea (HU)is an effective therapy for adults with sickle cell anemia;HU had a lower rate of painful events, acute chest syndrome, and need for transfusion compared with patients taking placebo $[19,20]$.Several small studies have reported the short-term toxicity and efficacy of HU for children with sickle cell anemia [21-24].

The aim of this study was to evaluate serum CK activity and serum inorganic phosphate levels in Sudanese patients with sickle cell disease.

Patients:

\section{Materials And Method}

This is a Descriptive cross sectional study, was conducted at Fath El Rahman El Basheir hospital Khartoum state -Sudan and Tandalti hospital White Nile state-Sudan. Approximately three months during the period from March to June 2016. 40 Sudanese patients with sickle cell disease (SCD) were in rolled in this study 
as a test group, and 40 a consecutive healthy individual was taken as control for each case. Patient with renal failure, diabetes mellitus, hypertension, were excluded from cases and controls.After signing an informed consent the medical history was taken from each participant (cases and controls) using questionnaire. Then five $\mathrm{ml}$ of venous blood was taken under septic condition from each group of the study, the sample allowed to clot, centrifuged at (3000rpm) for 5 minutes. The determination of creatine kinase (CK), and phosphorus levelsdone by using Quantitative spectrophotometric method.

\section{Statistical analysis:}

Data were entered into a computer using SPSS for windows (version 16.0). Significant differences between two groups were used student $(t)$ test. Data was presented as mean \pm S.D. The results were expressed in the form of tables, scatter. P value of $<0.05$ was consideredsignificant.

Ethics:

Ethical clearance was obtained from the research board at the Faculty of medical laboratory science, Alzaiem Alazhari University.

\section{Results}

This study was conducted in Fath El Rahman El Basheir hospital, Khartoum state -Sudan and Tandalti hospital White Nile state-Sudan.In order to evaluate CK, andPhosphorus level and its relationship with sickle cell anemia,the study was include 80 individual,40 patients with sickle cell anemia and another 40 healthy individual as control group. As in table (1) which compare the mean differences of CK in case $(255.2500 \pm 123.50122)$ and control group $(203.5000 \pm 63.06244)$ with $(\mathrm{P}=0.021)$. Also compare the mean differences of Phosphorus in the case $(5.080 \pm 1.3434)$ and control group $(5.250 \pm 1.1671)$ with $(\mathrm{P}=0.547)$.In the result showed in table (2) the mean differences of CK in male $(222.1500 \pm 126.63137)$ and female of in case $(288.3500 \pm 113.86755)$ with $(\mathrm{P}=0.090)$. Thecomparison of Phosphorus in male $(4.970 \pm 1.0883)$ and female of in case(5.190 \pm 1.5794$),(\mathrm{P}=0.611)$. The result was found significantly lower $\mathrm{CK}$ level among users of hydroxyurea $(220.9643 \pm 105.29060)$ than non-users $(335.2500 \pm 129.96862)(\mathrm{P}=0.006)$ as in Table (3).There were no significant differences of Phosphorus among users of hydroxyurea (5.325 .9493) and non-users was (4.508 $\pm 1.9174,(P=0.078)$, as in table (3). Scatter (1, and 2) showed no correlation between Ck,Phosphorusand age withR-value $=+280$ and $(\mathrm{P}=0.080)$, and $(\mathrm{R}-\mathrm{value}=-.319)$ and $(\mathrm{P}=0.045)$ respectively.

Table (1) Comparison the mean differences of CK and Phosphorus among case and control group.

\begin{tabular}{|l|l|l|l|}
\hline & Case & Control & P value \\
\hline CK U/L & $255.2500 \pm 123.50122$ & $203.5000 \pm 63.06244$ & 0.021 \\
\hline Phosphorus mg/dl & $5.080 \pm 1.3434$ & $5.250 \pm 1.1671$ & 0.547 \\
\hline
\end{tabular}

- $\quad t$-test was used to calculate $\mathrm{P}$ value

- P value less than 0.05 considered significant

- Mean \pm Std. Deviation

Table (2) comparison the mean differences of CK and Phosphorus among male and female of in case.

\begin{tabular}{|l|l|l|l|l|}
\hline \multicolumn{2}{|l|}{ Study group } & Mean \pm Std. Deviation & P value \\
\hline \multirow{3}{*}{ Case } & CK U/L & Male & $222.1500 \pm 126.63137$ & .090 \\
\cline { 3 - 5 } & & Female & $288.3500 \pm 113.86755$ & \\
\cline { 2 - 4 } & Phosphorus $\mathrm{mg} / \mathrm{dl}$ & Male & $4.970 \pm 1.0883$ & .611 \\
\cline { 3 - 4 } & & Female & $5.190 \pm 1.5794$ & \\
\hline
\end{tabular}

- $\quad t$-test was used to calculate P value

- P value less than 0.05 considered significant

Table (3) Comparison the mean differences of CK and Phosphorus among users and non-users of hydroxyurea in case group.

\begin{tabular}{|l|l|l|l|}
\hline & Use & Not use & P value \\
\hline CK U/L & $220.9643 \pm 105.29060$ & $335.2500 \pm 129.96862$ & 0.006 \\
\hline Phosphorus mg/dl & $5.325 \pm .9493$ & $4.508 \pm 1.9174$ & 0.078 \\
\hline
\end{tabular}

- $\quad t$-test was used to calculate P value

- P value less than 0.05 considered significant

- Mean \pm Std. Deviation 


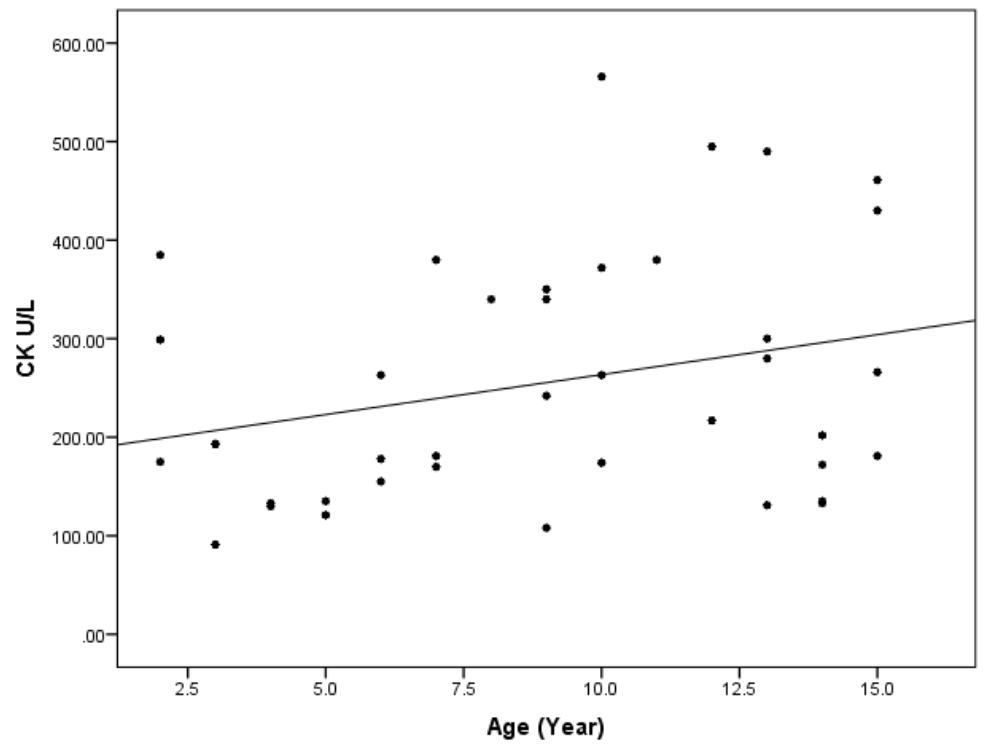

- Scatter (1): Correlation of age and CK in case group.

- $\quad$ R-value $=0.280$

- $\quad$ P- Value $=0.080$

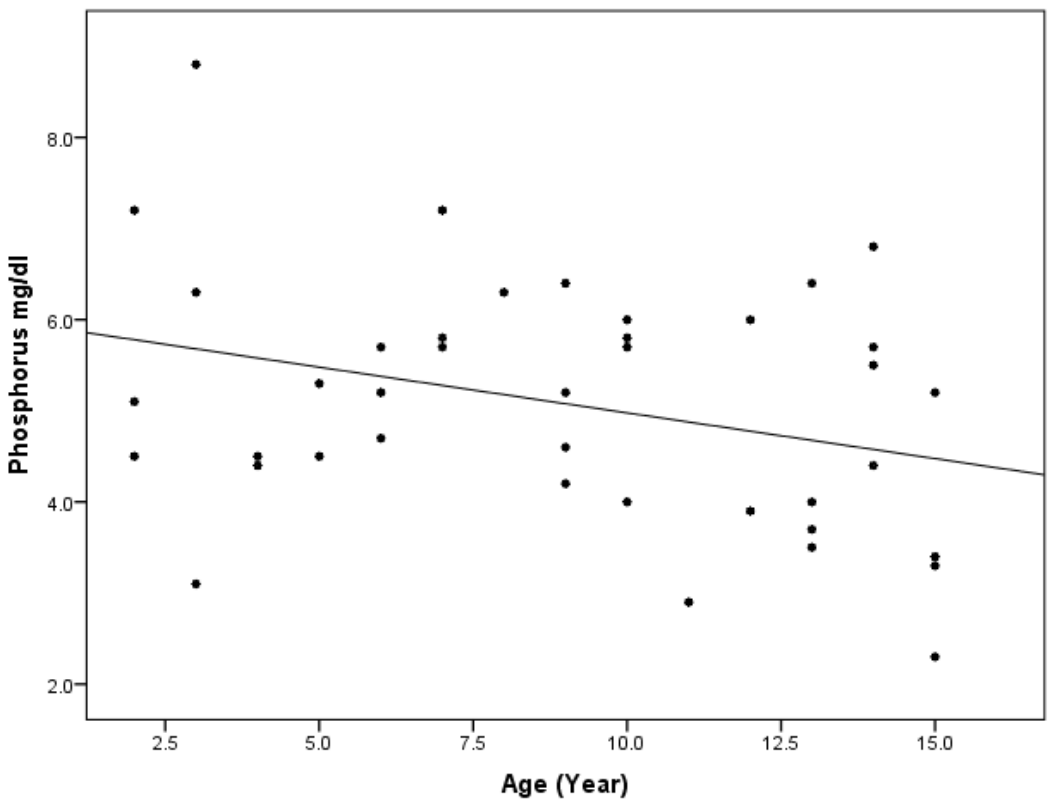

- Scatter (2): Correlation of age and phosphorus in case group

- $\quad$ R-value $=-0.319$

- $\quad$ P- Value $=0.045$

\section{Discussion}

The current study showed the mean of serum CK was significantly higher $(\mathrm{P}=0.021)$ in patients with SCD than control group (table -1). This finding agree with previous study conducted by Nnadi et al [25].The mean of serum phosphorus concentration showed a non-significant decrease $(\mathrm{P}=0.547)$ when compared with the control group(table -2), this agree with the previous study of Al harbi et al [27], Nnadi et al [25], and this is in contrast with the study conducted by Oladipo et al[26],who reported high level in adult and children .The study showed no significant difference in mean serum $\mathrm{Ck}$ level in male when compared to female with $(\mathrm{P}=$ 0.090), also there is no significant difference in mean serum phosphorus in male when compared to female $(\mathrm{P}=$ 
0.611).The study also revealed significantly decrease in serum $\mathrm{CK}(\mathrm{P}=0.006)$ in patients used hydroxyurea when compare with the patients not used hydroxyurea. While serum phosphorus showed no significant difference $(\mathrm{P}=0.078)$ between the patients used hydroxyurea and not used hydroxyurea. There is no correlation between $\mathrm{Ck}$ and age with $(\mathrm{R}$-value +0.280 and $(\mathrm{P}=0.080)$ also there is no correlation between phosphorus and age with (R-value - 0.319).

\section{Conclusion}

From the current study the sickle cell disease is a significant predictor of higher CK activity, while it is not significant predictor in serum concentration of inorganic phosphate.Monitoring of serum CK activity is advocated to enable early detection of rhabdomyolysis, a complication which may lead to renal damage, and eventually renal failure.

\section{Acknowledgement}

Authors would like to thank the patients from Khartoum and White Nile state who were involved in the study. Fund: None of the authors received any fund.

\section{Reference}

[1]. Rees DC, Williams TN, Gladwin MT. Sickle cell disease. Lancet 2010; 376:2018-31.

[2]. B. Modell and M. Darlison, "Global epidemiology of haemoglobindisordersandderivedserviceindicators, "Bulletinofthe WorldHealthOrganization, vol.86, no.6, pp.480-487, 2008

[3]. World Health Organization 2008, "Management of haemoglobin disorders," in Proceedings of the Report of Joint WHO-TIF Meeting, Nicosia, Cyprus, November2007.

[4]. F.B.Piel, A.P.Patil, R.E.Howesetal., "Globalepidemiologyof Sicklehaemogl obininneonates :acontemporarygeostatistical modelbased map and population estimates," The Lancet, vol. 381, no.9861, pp.142-151, 2013.

[5]. B. Modell, Ed., Guidelines for the Control of Haemoglobin Disorders, WHO, Sardinia, Italy, 1989.

[6]. G. R. Serjeant, "Sickle-cell disease," The Lancet, vol. 350, no. 9079, pp.725-730, 1997.

[7]. Piel FB, Patil AP, Howes RE, Nyangiri OA, Gething PW, Williams TN, et al. Global distribution of the sickle cell gene and geographical confirmation of the malaria hypothesis. Nat Commun. 2010; 1:104. [PMC free article][PubMed]

[8]. El-Hazmi MA, Al-Hazmi AM, Warsy AS. Sickle cell disease in Middle East Arab countries. Indian J Med Res.2011; 134(5):597610. PubMed | Google Scholar

[9]. Fedral Ministry of Health. Development of a national package for management of Sickle Cell Disorders. 8 Apr 2013. Khartoum. Available from: http://www.fmoh.gov.sd/Healthpolicy/Draft_PolicyBrief_SCD_Final.pdf.

[10]. Kaul DK, Fabry ME, Nagel RL. The pathophysiology of vascular obstruction in the sickle syndromes. Blood Rev. 1996; 10:29-44. [PubMed]

[11]. Rees DC, Williams TN, Gladwin MT. Sickle-cell disease. Lancet. 2010; 376:2018-31. [PubMed].

[12]. Pham PT, Pham C, Wilkinson AH, Lew SQ (2000) Renal abnormalities in sickle cell disease. Kidney Int 57:1-8

[13]. Osarogiagbon UR, Choong S, Belcher JD, VercelottiGM,Paller MS, Hebbel RP (2000) Reperfusion injury pathophysiology in sickle transgenic mice. Blood 96:314-320

[14]. Michael L, Bishop, Edward P, Fody, Larry schoeff clinical chemistry, principle, procedures and correlation, 6th editon. Lippincott, Williams and Wilkins.2010.

[15]. Baird MF, Graham SM, Baker JS, Bickerstaff GF. Creatine-kinase- and exercise-related muscle damage implications for muscle performance and recovery. J Nutr Metab 2012. 2012:960363. [PMC free article][PubMed]

[16]. Bhavsar P, Rathod KJ, Rathod D, Chamania CS. Utility of serum creatinine, creatine kinase and urinary myoglobin in detecting acute renal failure due to rhabdomyolysis in trauma and electrical burns patients. Indian J Surg 2013; 75:17-21.

[17]. Michael L, Bishop, Edward P, Fody, Larry schoeff clinical chemistry, principle, procedures and correlation, 5th editon. Lippincott, Williams and Wilkins.2005.

[18]. Prasad N, Bhadauria D. Renal phosphate handling: Physiology. Indian J Endocrinol Metab. 2013; 17:620-7. [PMC free article][PubMed]

[19]. Charache S, Baraton FB, Moore RD, et al- Hydroxyurea and sickle cell anemia.Clinical Utility of amyelosuppressive "Switching"agent. The Multi center study of hydroxyurea.1996

[20]. Charache S, Terrin ML, Moore RD, Dover GJ, Barton FB, Eckert SV, McMahon RP, Bonds DR. Effect of hydroxyurea on frequency of painful crisis in sickle cell anemia. N Engl J Med 1995; 332:1317.

[21]. Scott JP, Hillery CA, Brown ER, Misiewica V, Labotka RJ. Hydroxyurea therapy in children severely affected with sickle cell disease. J Pediatr 1996; 128:820.

[22]. Jayabose S, Tugal O, Sandoval C, Patel P, Puder D, Lin D, Visintainer P. Clinical and hematologic effects of hydroxyurea in children with sickle cell anemia. J Pediatr1996;129:559.

[23]. Ferster A, Vermylen C, Cornu G, Buyse M, Corazza F, Devalck C, Fondu P, Toppet M,Sariban E. Hydroxyurea for the treatment of severe sickle cell anemia: A pediatric clinical trial. Blood 1996; 88:1960.

[24]. Olivieri NF, Vichinsky EP. Hydroxyurea in children with sickle cell disease: Impact on splenic function and compliance with therapy. Am J PediatrHematol Oncol1998;20:26.

[25]. NnadiNnadi EE, Manafa PO, Okocha EC1, Chukwuma GO, Aneke JC1.Annals of Medical and Health Sciences Research | Sep-Oct 2014 | Vol 4 | Issue 5.

[26]. Oladipo OO, Temiye EO, Ezeaka VC, Obomanu P. Serum magnesium, phosphate and calcium in Nigerian children with sickle cell disease. West Afr J Med 2005; 24:120-3.

[27]. Al-Harbi N, Annobil SH, Abbag F, Adzaku F, Bassuni W. Renal reabsorption of phosphate in children with sickle cell nemia. Am J Nephrol 1999;19:552-4. 